\title{
Weatherhead Center
}

FOR INTERNATIONAL AFFAIRS HARVARD UNIVERSITY

\section{Ratings and Regulation: A Case of an Irreversible Marriage?}

by

Giulia Mennillo, PhD Candidate, University of St. Gallen and

Suryapratim Roy, PhD Candidate, University of Groningen

\section{Working Paper Series}




\title{
Ratings and regulation: a case of an irreversible marriage?
}

\author{
Giulia Mennillo and Suryapratim Roy *
}

September 18, 2014

\begin{abstract}
What are the rationales for policymakers to rely on putatively disinterested actors such as credit rating agencies (CRAs) for financial regulatory input? This paper draws on perspectives from International Political Economy and Comparative Legal Studies to analyze the reasons behind the use and retention of external ratings as an indirect instrument of financial regulation. We find that allowing 'market practice' to determine the relationship between ratings and regulation creates tautological justifications of the CRAs' authority, and raises compelling questions in terms of legitimacy.

The purpose of this paper is to uncover the constitutive elements of the tacit acquiescence underlying the subordination to CRA ratings in regulatory matters. The examination of possible conceptualizations of legitimacy may help conduct further inquiries into the politics of technocracy.
\end{abstract}

Keywords: Credit rating agencies, financial regulation, public-private authority, legitimacy

\footnotetext{
${ }^{*}$ Giulia Mennillo is a Ph.D. candidate at the University of St.Gallen (Switzerland). She is currently a predoctoral fellow at the Weatherhead Center for International Affairs, Harvard University (USA). Contact: gmennillo@wcfia.harvard.edu. Suryapratim Roy is a Ph.D. candidate at the University of Groningen (The Netherlands). Contact: surya.roy@rug.nl. We would like to thank Rawi Abdelal and the participants of the Society for the Advancement of Socio-Economics Conference 2014 for their helpful comments on earlier drafts, and Bernhard Forchtner, Dimitry Kochenov, Michal Krzyzanowski, and Timothy Sinclair for insightful discussions on several issues and perspectives that inform this working paper.
} 


\section{Introduction}

Among practitioners and scholars, a wide consensus has emerged that credit rating agencies (CRAs) ${ }^{1}$ have decisively contributed to the financial crisis of 2008. The accusation of 'rating failure' has been extremely popular in view of the systematically overoptimistic ratings of securitized financial products. As unanimous the critique may appear, different standpoints which go beyond "blaming the usual suspects" can be identified with regard to the reasons why the CRAs are considered as main contributers to the financial crisis (Sinclair 2010).

We argue that the incorporation of external ratings into financial regulation in different legal systems co-constitutes the CRAs' influence and authority on financial markets. This implies that a discussion about the role of CRAs in contributing to the financial crisis, including the impact of the criticized 'rating failure,' cannot ignore an analysis into the conditions and rationales that turned ratings into an instrument of financial regulation. ${ }^{2}$

In many regulatory frameworks, the determination of capital requirements of banks relies on risk-weighting of assets. The risk differentiation itself is usually undertaken by credit ratings. For example, within the "standardized approach' of the 'Basel III accord' risk categories are constituted by external ratings which are delivered by the CRAs. ${ }^{3}$ Though being opinions about credit risk which per se cannot be 'accurate' or 'inaccurate,' the "distinctively portable format and scientific appearance" of ratings (Carruthers 2013, p. 544), fortified by the impression of relative measurability through the ordinal scale, seem to legitimize the ratings' qualification as regulatory instruments - a temptation regulators (among others) are not able to resist. This conception translates into a 'marriage' between ratings and regulatory requirements which then transforms 'opinions' into de facto stipulations according to which issuers and investors have to act.

Linking capital adequacy requirements (CAR) to external ratings has led to criticism in terms of the procyclicality of capital buffers in financial markets. Connecting risk assessment systematically to CRA expertise tends to

\footnotetext{
${ }^{1}$ In this paper, the acronym 'CRAs' refers to the three largest credit rating agencies (also known as the 'big three'); Fitch Ratings, Moody's and Standard \& Poor's Ratings Services, which hold approx. 95\% of market shares (Rügemer 2012).

${ }^{2}$ Other scholars who similarly attribute the contribution of CRAs in causing, or triggering, the financial crisis to the role ratings play in financial regulatory matters are, e.g., Partnoy (2009) and Dullien (2013).

${ }^{3}$ Next to the 'advanced internal ratings-based' (A-IRB) approach, the here mentioned 'standardized approach' was also part of the first pillar of the Basel II accord covering minimum capital requirements. For an informative and critical discussion of Basel II and its successor Basel III, see Lall (2012).
} 
harmonize market risk perception. ${ }^{4}$ For example, if credit risk perception is excessively optimistic as reflected in high ratings, this implies that the overall capital buffer in the financial system decreases. In 2008, it bluntly manifested to be 'too low.' Since legal systems not only award, but also impose on ratings the status of a state-approved seal of creditworthiness assessment, especially in times of crisis, CRAs' comments, announcements, outlook changes, and actual rating changes (and their anticipation) materialize in herd behavior and mechanistic market responses. These rating-induced cliff effects, facilitated and exacerbated by its regulatory license (Partnoy 1999), stands in sharp contrast with the CRAs' original mandate of mitigating the market's risk perception. Thus CRAs themselves may be ambiguous in terms of their automated influence resulting from their embeddedness into regulatory frameworks.

As stated, the role CRAs played in contributing to the crisis can be attributed to different lines of argument; e.g., to the over-optimism in risk perception; to conflicts of interest inherent in the issuer-pays business model; to the timeliness between credit ratings and the market's risk perception; or, to the incorporation of ratings into financial regulation. In this article, given our general interest in the social construction and legal codification of expert opinion, we focus on the latter explanation. This is not meant to trivialize the relationship between rating failure, market perception and financial instability - the correction of the misrepresentation of risk and uncertainty may still be one of the most difficult tasks regulators, CRAs, financial institutions and academia have to address in the aftermath of the crisis (Katzenstein \& Nelson 2013). But as important the prevention of rating failure and the aiming for best practices may be, this is not sufficient to account for the authority of CRAs, or accountants, in global financial markets.

Questioning the conveyed impression of 'mission accomplished' by policymakers and regulators, a substantial body of literature examines the ongoing regulatory efforts in the U.S., EU, and on the transnational level (e.g., see Brummer \& Loko (2014), Darbellay \& Partnoy (2012), Porter (2010)). We want to add a further perspective to this debate, which in our view has not yet received the attention it deserves, namely the analysis of the use, and retention of ratings as instruments of financial regulation. ${ }^{5}$ Retracing the mechanisms which have led to this institutional "dubbing" (Besedovsky

\footnotetext{
${ }^{4}$ This is even fortified by the fact that the ratings of the CRAs are correlated (Gaillard 2012).

${ }^{5}$ This refers in particular to Basel III. In the U.S., the Dodd-Frank Act requires the removal of references to ratings in statutes and regulations; this is being effected by the SEC on a piecemeal basis. For developments in this regard, see: http://www.sec.gov/spotlight/dodd-frank/creditratingagencies.shtml.
} 
2012) and its continuity, shall enable us to conduct the debate on the appropriateness of the regulation of CRAs and, last but not least, on the prevention of the next financial crisis in a more nuanced perspective.

The paper is structured as follows: Firstly, we discuss the so-called 'agency paradox' since our interest in the rationales of the regulatory incorporation of ratings directly adheres to this concept. In a second step, we examine the legitimacy of the relationship between ratings and regulation. The third section analyzes possible exit strategies. The paper ends with a brief conclusion.

\section{The 'agency paradox'}

One of the main purposes of this paper is to shed light on the so-called 'agency paradox.' This paradox refers to the contradictory stances towards credit ratings taken by policymakers, central bankers and regulators - namely the "simultaneous criticism of and increasing reliance upon credit ratings" (Bruner \& Abdelal 2005, p. 205, emphasis added). In view of the financial crisis which, on the one hand, brought about an increased criticism of CRAs and, on the other hand, has not yet led to a substantial decrease of the reliance upon external ratings in the standardized approach of the Basel III accord, this paradox appears even more exacerbated.

Concerning the above mentioned question of the CRAs' responsibility for the financial crisis, the U.S. Department of Justice appears to be stuck in a complicitous trap, for "if S\&P were really guilty of fraud, then the U.S. regulatory architecture would have to be named as its primary accomplice" (Abdelal \& Blyth 2013, p. 26). Above all in Europe, when governments were facing sovereign rating downgrades during the crisis, the concomitant "complaints by sovereigns" about the influence of CRAs, and the fact that this influence was created by governments themselves, shows the odd implications of the 'agency paradox' in practice (Abdelal \& Blyth 2013, p. 5).

As we consider the post-crisis transnational efforts of CRA regulation being endogenously related to the use of ratings in regulation, we regard both dimensions of the agency paradox to be interrelated, too. The crisisinduced visibility of the transferred authority contributed to an increase in the criticism of CRAs. This criticism materialized in an enhanced regulation of CRAs, which may underpin and, possibly, even have a legitimizing effect on CRA rating reliance in regulation. Thus the agency paradox seems to reinforce itself by its own consequences.

Our interest into the rationales of the regulatory incorporation of ratings aims at reconstructing the conditions under which the agency paradox could come into being and persist. It appears that the incorporation has been 
accompanied by a tacit consensual acceptance of the discursive tautologies and inconsistencies of this regulatory arrangement, laying the ground for its longevity. ${ }^{6}$

Up to the financial crisis, the apparent stability of this regulatory arrangement seems to have relied on what Bruner \& Abdelal (2005, p. 210) call a successful "quid pro quo." The notion of a 'win-win situation' seems to have nourished the desirability of this co-operation. In the following paragraphs, the ceteris paribus conditions, on which this reciprocal exchange between the CRAs and public authorities seems to be based, are briefly discussed. For "any compelling prediction of how [something] will end must begin with what sustains it" (Norrlof 2014, p. 25).

The co-operative arrangement discussed here allows governments and regulators to delegate the "political accountability" for the public's exposure to credit risk to the CRAs, which are "making the sorts of judgments otherwise (and previously)" made by public authorities (Abdelal 2007, p. 171). The loss of public authority in matters of financial regulation is exchanged for less political responsibility in case of regulatory failure. Concurrently, the regulatory use of ratings creates an artificial demand for ratings, and confers "a quasi-official stamp" of credibility to the CRAs. The interaction of these two mechanisms switches off market discipline. Granting "regulatory licenses" (Partnoy 1999, p. 623), implies that major incumbent CRAs can never be wrong (White 2001). ${ }^{7}$ Moreover, by the near absence of direct regulation, CRAs do not encounter onerous interference into their business activity. All these effects taken together end up creating a public, protective shield against new competitors (Bruner \& Abdelal 2005, p. 203).

The other side of the coin is that CRAs have to incur a reputational risk, namely to play the scapegoats "when things go wrong." 8 This represents the corollary to the delegated political accountability. Given that CRAs decided voluntarily to engage with this arrangement, apparently, the reputational risk was considered to be very low in contrast to the expected benefits.

\footnotetext{
${ }^{6}$ Admittedly, this argument dilutes the question of the awareness and 'know-ability' of the undesired effects of the arrangement - be it 'known unknowns' or 'unknown unknowns.' Not least, this impacts also the limited spectrum of available alternatives to ratings-dependent regulation (see section below on exit strategies).

${ }^{7}$ Ratings are less and less demanded on a voluntary basis in a 'take it or leave it' logic (which would be in accordance to the original business idea of the rating industry), but because issuers and investors are legally obliged to take ratings into account. Whether a market participant's own judgment is in line with the judgment of a CRA, is futile.

${ }^{8}$ 'Scapegoats' in a purely reputational, and not in a legal sense. Due to the legal status of CRAs as First Amendment 'opinion-expressing' entities, with few exceptions, it has been hardly possible to hold CRAs liable for the consequences of their ratings (see legitimacy section below).
} 
If the simultaneous "dissociation of power and accountability, and the dissociation of reputation and market demand" (Bruner \& Abdelal 2005, p. 211) are ingredients of the formula of this regulatory arrangement, then it remains to be seen to what extent the negative externalities deriving from this double dissociation either develop a self-destructive dynamic, or are still bearable to sustain the arrangement further. Metaphorically speaking, the consequences of this 'marriage' may either shake its foundations to put at risk the marriage at a whole, or render the marriage yet more irreversible thus perpetuating the paradox.

The dissociation of power and accountability leads to Kerwer's (2005) 'accountability gap;' a situation which is characterized by a "persistent mismatch between demand and supply of accountability." The experience of the last years has brought the negative externalities resulting from this gap to the fore. They seem to have taken on a dynamic of their own, undermining the conditions under which the tacit deal was originally closed. In an attempt to mitigate the lack of accountability that this regulatory arrangement has produced, governments are now trying to tame the spirits they have invoked by modifying one of the ceteris paribus conditions under which the quid pro quo with the CRAs came into existence. As a response to the crisis, the accountability gap is not closed by the realignment of power and accountability, but by increasing the regulation of CRAs. As a result, the increasing regulatory burden, plus the reputation at stake for CRAs due to the crisis, has put the use of external ratings for regulatory purposes to the test; the erstwhile 'win-win situation' may come "increasingly under threat" (Bruner \& Abdelal 2005, p. 2010). At the same time, it is the ambiguity of the effects of the new regulations that makes it difficult to make a prediction regarding the end of the paradox.

Policymakers tend to frame the recent reforms in terms of the regulation of CRAs as a success story for the 'lessons learned' from the crisis. Likewise, the regulation of CRAs has served as an apparent showcase for successful transnational governance. ${ }^{9}$ Besides the establishment of the 'IOSCO Code of Conduct,' CRAs are becoming subject to intensified regulation and oversight on both sides of the Atlantic, visible in the foundation of the Office of Credit Ratings under the Securities and Exchange Commission (SEC) in the U.S. and the European Securities and Markets Authority (ESMA) in the EU.

It could be argued that policymakers, by apparently fixing an alleged failure in the system, at least try to get the 'wrongs.' However, if we assume

\footnotetext{
${ }^{9}$ According to the Eurobarometer of autumn 2013, $78 \%$ of the surveyed "would like to see [...] tighter rules for credit rating agencies." This may be indicative for the continued political pressure in the EU to regulate CRAs.
} 
that the regulatory use of ratings has laid the breeding ground for the impact potential of the rating failure in the first place, then an alternative way to argue is that the crisis has made the deficiencies of this regulatory approach visible - transforming the role of private, profit-maximizing firms into stateapproved "auxiliary monitors" (Claessens \& Kodres 2014).

We thus conceive of the recent efforts to regulate CRAs as endogenous to the regulatory use of ratings. It is therefore not surprising that CRAs, partly, do not welcome the new regulations. ${ }^{10}$ The overcharging of the role of CRAs implies that attempts to modify the existing framework will probably be perceived as an excessive "intrusion into [the CRAs'] operations" (Bruner \& Abdelal 2005, p. 209). The overcharged role translates into an excessive influence which then obliges regulators to put CRAs under excessive scrutiny in the moment the delegated authority becomes visible, i.e. during a crisis.

At the same time, there are also reasons to presume that CRAs may benefit from the new regulations; the existing oligopoly may be cemented, and the legitimacy of ratings as a regulatory tool may even increase. Considering the fact that CRAs welcome the compliance with the IOSCO Code of Conduct, this could be interpreted as an interest of CRAs to maintain the international financial standards-regulation nexus. These counteracting forces - the aversion towards excessive oversight, and the benefits originating from the CRAs' membership to the transnational financial governance regime - can be regarded as the critical setscrews upon which the 'marriage' of ratings and regulation depends.

In the aftermath of the crisis, CRAs themselves have taken contradictory stances concerning the regulatory reliance on external ratings. Voices were raised to be taken out of the regulatory frameworks. ${ }^{11}$ It could be expected that CRAs, given their reputational capital, are capable of maintaining their oligopolistic market position even without artificial regulation-induced market demand - through self-reinforcing, reputational scale effects and the stickiness of market practice. However, CRAs do not welcome the idea of an entire abolition of external ratings either, which suggests the anticipation of significant economic losses in such a scenario.

The expressed desire to be taken out of the regulatory framework may be interpreted as a shying away from, and a confession of, the agencies' own market influence. Mechanistic market responses triggered by rating events are

\footnotetext{
${ }^{10}$ Regulatory measures include tighter transparency and reporting requirements, and increased liability. In an academic panel discussion (2012), a high ranked CRAs' representative complained about the increased regulatory oversight for being "almost physical."

${ }^{11}$ In the context of an academic panel discussion in 2012, a high ranked CRAs' representative emphasized the apparent CRAs' efforts to seek exemption from regulatory incorporation.
} 
particularly observable in times of crisis. If 'herd behavior' and 'cliff effects' are associated with CRAs, then the regulation-induced market power may reveal to be harmful for maintaining the reputational capital of the CRAsa critical asset of the rating business. The visible power 'to govern capital flows' gives rise to criticism and puts CRAs in the public spotlight, regardless of the fact that this power has been originally facilitated by regulation.

Such a perceptional distortion necessarily follows from the dissociation of the regulatory framework from the rule content. Although CRAs are formally not liable for their authorship, the are discursively held responsible for the effective moving of markets. Whether the complex interactions of these dynamics were anticipated by the CRAs before engaging with the quid pro quo, remains a big question mark.

In this article, we regard the incorporation of ratings into financial regulation as one factor that re-enforces the "epistemic authority" of the CRAs (Sinclair 1999, p. 165). Before discussing this line of argument in more detail, for the sake of completeness, we want to mention briefly a further effect of ontological nature: In a polysemic fashion, ratings have become to mean opinions, judgments, technical products, stochastic measurements, self-imposed investment standards up to regulatory constraints and hence 'quasi-law' at the same time. These different definitions and understandings of 'ratings' change according to contexts, situations and discursive positions. The semantic multiplicity seems to lead also to tensions and divergences in the selfperception of CRAs. According to Besedovsky (2012, p. 228), rating analysts tend to view themselves in a research role, whereas, management representatives tend to stress the equivalence of their business with the work of a 'nominal First Amendment journalist' (Bruner \& Abdelal 2005, p. 210). ${ }^{12}$ Although there may be also further factors promoting the polysemy of ratings, the empowerment via regulatory incorporation has certainly played a crucial role in this process.

With regard to sovereign ratings in particular, the acceptance of the CRAs' authority in the regulatory cloak is equal to a tacit subordination to the normative, and thus political, predispositions of the rating methodology. For example, Bruner \& Abdelal (2005) argue in favor of achieving a deeper cognizance of the "perceptual and ideological underpinnings" when "ratings are given the force of law." Whether policymakers were aware of this normative-political dimension following the empowerment of ratings remains unclear. Policymakers seem to tacitly accept, and perhaps even welcome the fact, to be subject to "the authority of unaccountable firms to define - or at

\footnotetext{
${ }^{12}$ The characterization of CRAs as 'journalists with benefits' has been legally influenced and endorsed, as will be discussed below.
} 
least reproduce - the terms of orthodox economic policy making" (Bruner \& Abdelal 2005, p. 211), instead of assuming responsibility for the regulation of credit risk themselves.

It may not constitute a puzzle that the U.S. government does not find it difficult to subordinate itself to institutions which supposedly "enforce U.S.centric governance norms abroad." However, this perspective may fall short given the recently more active, commentary intrusion of CRAs in the public discourse about, e.g., U.S. domestic policy issues such as the debt ceiling or shutdown debates.

When it comes to European policymakers, the interest of imitating the American empowerment of CRAs is more puzzling. What kind of rationale may have driven them? Is it the overlap of certain norms which Europeans may want to see enforced through the CRAs? Admittedly, this paper cannot give exhaustive answers to these questions. We nonetheless suggest that the empowerment of ratings has been favored by a technical understanding of ratings, an understanding which tends to obfuscate the awareness for the "ideological underpinnings" of ratings and its normative implications.

This is not to say that sovereign ratings in general, cannot serve as a relational power instrument by policymakers to enforce certain behaviors in bargaining situations. At the same time, the recent experience of the European sovereign debt crisis has revealed quite bluntly that policymakers and EU institutions, instead of relying on CRAs' claims to enforce certain standards, absorbed and advocated these standards by themselves. This may suggest that the intentional instrumentalization of CRAs as standard enforcers was not a central rationale of the empowerment of CRAs. Nowadays in Europe, 'austerity' or 'fiscal consolidation' seem to be rather associated with the 'troika' than with the sovereign rating practice. ${ }^{13}$

Considering the fact that the empowerment of CRAs has been undertaken long before the crisis, it may not come as a surprise that European policymakers were probably not aware of the epistemic authority and its consequentiality they were underpinning. However, the consciousness in this regard may have awakened in the course of the sovereign debt crisis. Brummer \& Loko (2014) raise this argument indirectly in their comparison of the regulatory reforms on CRAs between the U.S. and Europe. They find a stronger regulatory impetus in the EU. They explain these differences in light of the criticism CRAs faced with their excessive downgrades of European sovereign debt in the last years.

This finding points to an interesting antagonism in terms of the political

\footnotetext{
${ }^{13}$ For example, see "[s]trikes a barometer of Europe's austerity tolerance," BBC News Europe, Gavin Hewitt, 14 November 2012, retrieved 18 June 2014.
} 
willingness to reduce the CRA rating reliance in regulation. The Financial Stability Board (2013) claims that the EU would have made "significant progress," however, the U.S. would have moved "furthest" when it comes to the removal of hard-wiring reliance on ratings in regulation. The different approaches to solve the agency reliance - the EU having a stronger regulatory impetus on CRAs, whereas the U.S. going beyond Basel III via the direct removal route induced by Dodd-Frank - might indicate that the agency paradox, though created in the U.S., may even have a longer half-life in Europe.

\section{Legal Legitimacy of the Relationship be- tween Ratings and Regulation}

\subsection{Law as Policy, Law as Values}

Historically, and especially over the last two decades, the diffusion and transplantation of law has occurred primarily in two ways. The first is the one that characterizes the law of finance and other forms of 'law as policy' - the proliferation of expert governance to ensure uniformity and efficiency. ${ }^{14}$ The other relatively less visible form is law arising out of constitutionalism and administrative law with an affinity for principles of natural justice. The latter is put into motion primarily through the judicial discourse of younger democracies, and supranational courts and tribunals. The EU is an interesting case where both forms of law can be found. While 'law as policy' is the primary approach adopted in the EU, constitutional values and principles of natural justice (or 'law as values') have featured in 'hard cases' arising out of citizenship, as the EU is increasingly concerned with aspects of life other than the free movement of goods and services (Kochenov 2008).

Unfortunately, these two ways of understanding and applying law are not on conversational terms, and this affects both schools of practice. It may be pointed out that such a conversation has been traditionally considered unnecessary in a domestic legal system that follows a strict division and separation of powers, where the ontologies that animate expert governance and constitution-based relief could be kept apart. The problematic nature of this separation becomes obvious in the current transnational legal order where the nation-state is no longer the sole or the most important authority for determining which discourse has normative force, ${ }^{15}$ or which institutions

\footnotetext{
${ }^{14}$ This form of law animates the discussions of legal sociologists such as Carruthers \& Halliday (2007) and Dezalay \& Garth (2011).

${ }^{15}$ For public international law, it could be argued that the State still retains the authority to implement law (Hollis 2005), however, such type of authority is compromised for
} 
yield power. Thus, the traditional separation of the ontologies of law-and the institutional discourse that flows from it - can no longer be relied on as a basis of legal authority. In the absence of a dialogic space where these two ways of approaching law meaningfully interact, the situation is not one where the two exist in harmonious mutual respect, but one where the latter defers to the former in the shaping of the transnational legal order. This explains why concepts such as 'rule of law' or even 'administrative law,' once a signifier of normative values that legislative and executive decisions encapsulated or failed to encapsulate, now serve an instrumental purpose of implementing the preferences of wielders of transnational power. Identifying the existence of institutions or formal procedural requirements as satisfactory conditions for the rule of law (Carruthers \& Halliday 2007, p. 128) is the usual mechanism by which this deference is carried out. Hence, formal identification leaves the normative basis of law incontestable through the $d_{o x a}{ }^{16}$ of formal institutional discourse.

In their characterization of the Basel framework as a commendable form of Global Administrative Law, Barr \& Miller (2006) argue that expert international governance may be preferable to national law, as elite domestic actors may not be suited or may corrupt the governance of complex issues such as financial stability. They qualify their analysis with the observation that 'global administrative law' should be made more participatory. We do not disagree with Barr \& Miller (2006) that elite domestic actors may be less legitimate authorities than transnational actors when it comes to financial governance. We are rather concerned whether a claim to expertise that is difficult to verify is sufficient to endow private governance with public authority.

With the transnationalization of governance, alternatives to the exercise of power by elite domestic authorities have emerged. This is indeed a step in the right direction for a more reasoned debate on normative considerations and the use of empirical research in national constitutional and administrative law. However, we think this is a one-way street, where existing domestic values can be questioned as to whether they constitute efficient and determinate policy, while expert policies cannot be questioned against the values they endorse. In our view, what cements this one-way street is the construction of the epistemic power of experts as legal authority.

From the above formulation, it may appear that we prefer domestic values over transnational expertise. We wish to clarify that we make no such

transnational law.

${ }^{16}$ We refer to Bourdieu's (1977) conceptualization of doxa as the naturalized political language of understanding and contestation: the manner in which "every established order tends to produce [...] the naturalisation of its own arbitrariness." 
claim. Rather, characterizing the assessment of legitimacy of law as confined to a preference for a particular authority (domestic or international) would render such an exercise tautological, or instrumental in the naturalization of institutional power. Our concern lies instead with the structural epistemic authority that expert governance enjoys, which shapes the doxa of justifying allegiance to it, or deviation from it. While epistemic authority may be an essential property of expertise, we argue that such authority in itself does not constitute legal legitimacy if we were to provide space to the 'law as values' approach. Facets of constitutionalism and administrative law that inform the 'law and values' approach entail working towards a culture of justification away from a culture of authority (Cohen-Eliya \& Porat 2011). As the contestation of legislative and executive acts and the fostering of meaningful participatory governance are essential facets of constitutional and administrative law, the fact of epistemic expertise does not satisfy legal legitimacy.

What appears to escape scholarship regarding international financial regulation is that the dominance of international organizations and their products are not assessed according to whether they include the property of contestability, and reason-responsiveness. On the contrary, the concentration is on the improvement of the accountability and transparency of domestic elites, and the inculcation of pragmatic law-making through the proliferation of international standards. ${ }^{17}$

Huault \& Richard (2012) characterize international finance as a "discreet regulator;" the alleged commensurability of credit allocation and the harmonized governance of investment are forms of regulation, or "that which creates regularity." Regulation is thus a mechanism of instilling and maintaining order in relation to any functional end. This understanding is very different from how regulation is understood in a legal sense, where regulation is a method of delegated legislation, or a convenient mechanism to achieve legal ends (Ward 1996). For this reason, regulations within national legal orders can be struck down for deviating from the legislative principles and constitutional values under which they are instituted.

It may be worth noting that what is suggested above is not an argument regarding a 'right' to obtain reasons, or a formal process of requiring organizations in positions of authority to provide reasons. Instead, what is highlighted is the requirement to foster a culture of justification, where authority can be negotiated through contestation, implying an ongoing process of assessment of the legitimacy of authority by different stakeholders affected by such authority. In other words: It is the property of contestability that

\footnotetext{
${ }^{17}$ Dezalay \& Garth (2011) have shown that this could be attributed to the incentives and networks of elite lawyers, who seek transnational commercial mobility.
} 
needs to mediate the relationship between ratings and regulation. Currently, the justification for the use of ratings relies on the epistemic authority of organizations adjudged to be experts, which in turn rests on their assumed ability to assess credit risk in a 'forward looking' manner. ${ }^{18}$ We shall seek to show in this section that this is a legitimizing strategy of the normativity of financialization (Krippner 2011, van der Zwan 2014). While financialization may be an instrumental way of satisfying legal values representative of the public interest such as arriving at and maintaining social order through economic stability, its legitimacy as a normative end of law is questionable.

The promotion of contestability necessitates an interrogation of whether this functional end is suitable for informing all aspects of the relationship between ratings and regulation, and the method of interrogation requires the availability of credible alternatives to assess the comparative benefit that CRAs and ratings have to offer. ${ }^{19}$ For this purpose, a discussion on the relationship between ratings and law is warranted.

\subsection{The relationship between law and ratings}

Most of the post-crisis legal and scholarly literature on CRAs concentrates on their responsibility in facilitating the crisis (Harper 2011, Ellis et al. 2011), and on the enhancement of regulatory oversight. However, to assess the agency paradox and the path-dependent influence of ratings, we take a step back to assess the legal relationship between ratings and regulation under U.S. law and in the European Union, and the phenomenon of transnational private governance as a source of law.

\subsubsection{Genesis of the relationship between ratings and regulation under U.S. law}

The genesis of the influence of CRAs in regulation is attributed to a moment in American legal history when a statutory acknowledgment of a regulatory act endorsed the rating of securities. The Comptroller of the Currency of the U.S. Department of Treasury endorsed ratings as the appropriate mechanism to assess the quality of the national banks' bond accounts in 1931 (Partnoy 1999, pp. 688-690); this was picked up in the Banking Act and the Federal

\footnotetext{
${ }^{18}$ Testimony of Deven Sharma, President, S\&P, before the United States House of Representatives Committee on Financial Services, Subcommittee on Oversight and Investigations, 2011, pp. 3 and 10; Testimony of Michael Rowan, Managing Director, Moody's, before the United States House of Representatives Committee on Financial Services, Subcommittee on Oversight and Investigations, 2011, pp. 4 and 8.

${ }^{19}$ For a discussion of the 'comparative benefit standard,' please see p. 26 below.
} 
Reserve Act of 1936. The defining moment was a ruling by the Comptroller on February 15, 1936 defining what an 'investment security' is:

The purchase of 'investment securities' in which the investment characteristics are distinctly and predominantly speculative, or 'investment securities' of a lower designated standard than those which are distinctly and predominantly speculative is prohibited.*

*The terms employed herein may be found in recognized rating manuals, and where there is doubt as to the eligibility of a security for purchase, such eligibility must be supported by not less than two rating manuals.

As Partnoy narrates, this ruling had "an explosive effect" with more than half of the publicly traded bonds falling foul of the favored definition of securities. At the same time, the bonds approved by the CRAs substantially appreciated in value. The ruling was crucial for the role that CRAs were to play; for the first time, bonds were rated prior to their issue (Partnoy 1999, p. 689).

Subsequently, the accreditation of the leading CRAs as 'Nationally Recognized Statistical Rating Organizations' (NRSROs) by the Securities and Exchange Commission (SEC) in $1975^{20}$ is usually heralded as a turning point in the reliance placed on credit ratings by regulators and their pervasiveness with respect to various regulations (Heggen 2010, p. 1751; Nagy 2009, p. 144). By validating the superiority of the ratings provided by the NRSROs over journalistic opinions or other forms of non-professional speech, the SEC endorsed the view that the "[NRSROs's] ratings are not the equivalent of editorials in the New York Times" (Nagy 2009, p. 161). Specifically, Rule 15c3-1 issued by the SEC allowed relaxed 'haircut' requirements for bonds and securities accredited by the NRSROs. ${ }^{21}$ This may explain the regulatory and statutory dependence that was to follow, whereby ratings were endorsed in "hundreds of regulations" and domains of law including securities, pension, banking, real estate, and insurance regulation (Nagy 2009, p. 161). Not least among the bodies that endorsed the ratings was the SEC itself in its

\footnotetext{
${ }^{20}$ Out of the seven CRAs granted CRA status in 1975, only the 'big three' remained in 2003 after a wave of mergers (Amtenbrink \& Heine 2013, p. 3).

${ }^{21}$ This provision has been amended by the SEC (effective from July 7,2014 ) to remove the enjoyment of lower haircuts with regard to "commercial paper, nonconvertible debt, and preferred stock" rated by the NRSROs. Securities and Exchange Commission, Removal of Certain References to Credit Ratings under the Securities and Exchange Act of 1934, RIN 3235-AL14, available at: https://www.sec.gov/rules/final/2013/34-71194.pdf.
} 
various administrative actions, such as the exempting funds from valuation requirements if their portfolios contained NRSRO rated securities, or issuing a stamp of 'investment grade' to those securities rated as such. ${ }^{22}$ As Enron's securities were rated as 'investment grade' until four days before its collapse, the Congress investigated the role of CRAs in contributing to the collapse, including hearing testimonies from agencies and various stakeholders. This investigation eventually culminated in the Credit Rating Agency Reform Act 2006, and rules regarding the oversight of CRAs issued by the SEC in 2007, 2008 and 2009.

What might seem unusual is the motivation behind the regulatory interest in CRAs around 1975 that substantially contributed to the public-private ratings complex that exists to the present day. The New York City bankruptcy in 1974 (that had a network effect on the payment of pensions and social services in other cities, and required a bail-out by the federal government) was not predicted appropriately in the ratings offered by S\&P's and Moody's on the city's bonds until late 1974 (Brummer \& Loko 2014, p. 158; Sicilia 2011). This prompted the need for regulatory oversight leading to the regulations discussed above. Paradoxically, the failure of CRAs led to the regulatory endorsement of the CRAs. In part, this was due to institutional failure, as the SEC readily granted NRSRO status to the CRAs involved in New York's bankruptcy, but were hesitant in providing such status to other agencies or assessors (Brummer \& Loko 2014). Although the 2006 Act led to the authorization of a few more agencies, the Act did not provide the SEC with any new powers to control the substance of ratings, nor did it interfere with the issuer-pays model. Tracing the history of CRAs in the American regulatory space, Brummer \& Loko (2014, p. 156) observe that what really makes CRAs unique in contrast to other market players is their embeddedness in regulatory regimes and practices.

In addition to regulatory endorsement, judicial discourse cemented the informational and reputational advantages enjoyed by CRAs by distinguishing the services provided by CRAs from other services integral to financial products and regulations. Over the years, there have been attempts to hold CRAs liable for the ratings they provided under grounds of negligence, or professional misconduct. ${ }^{23}$ In all these cases, the CRAs invoked the Firstamendment defense, arguing that their ratings are not services, but speech, and hence are protected from liability. Until recently, this line of defense has

\footnotetext{
${ }^{22}$ SEC Money Market Funds Rule, 17 C.F.R. $§ 270.2 a-7(a)(9)$ (2009); SEC Forms for Registration Statements, 17 C.F.R. $§ 239.13$ (2009).

${ }^{23}$ The most relevant cases in this regard are: Quinn v. McGraw-Hill, 168 F.3d 331 (7th Cir. 1999), In re Fitch, Inc., 330 F. 3d 104, 110 (ed Cir 2003), Abu Dhabi Commercial Bank v. Morgan Stanley \& Co., 651 F. Supp. 2d 155 (S.D.N.Y. 2009).
} 
been largely accepted by courts in different jurisdictions, allowing CRAs the unique position of being immune from professional liability unlike regular financial service providers, and at the same time, of providing opinions that enjoy much greater regulatory and statutory interest and weight than other forms of 'free speech' such as 'a New York Times editorial.'

By facilitating a 'power without responsibility' framework for CRAs, the unique judicial law of ratings influenced a deep relationship between law and ratings. It may be asked whether recent lawsuits filed against rating agencies by government bodies, as well as holding them liable in some jurisdictions, ${ }^{24}$ signal a change in this embedded relationship. It is unclear whether this sudden shift in the jurisprudence of the liability of rating agenciespossibly influenced by post-crisis public and political interest-would alter the regulatory and statutory dependence on ratings. In this regard, though the concentration on the judicial cognizance of ratings has been with respect to determinate issues such as extending accountability for professional misconduct, or the circumstances when the free speech defense is not applicable to commercial speech, such cognizance plays a broader role of expanding the hermeneutic space regarding the normative use of ratings. This discursive advantage is not enjoyed in the European legal order, ${ }^{25}$ where concerns regarding standing and reliance on expert governance may foreclose addressing concerns of social and moral legitimacy ${ }^{26}$ through the judicial process.

\subsubsection{Diffusion of the relationship between ratings and regulation through transnational governance mechanisms}

The primary regulatory response to 'rating failure' in the EU has been promulgated by the European Council in 2009, and is considered to be "the most comprehensive regulation of CRAs to date" (Charles 2010, p. 401). Prior to this, CRAs were left largely outside the ambit of federal regulation, limited

\footnotetext{
${ }^{24}$ The Federal Court of Australia is the first court in the world to reject the free speech defense and found Standard \& Poor's AAA rating "misleading and deceptive" in a class action suit filed by twelve local councils. Bathurst Regional Council v. Local Government Services Pty Ltd (2012) FCA 1200. After this judgment, 'copycat litigation' has led the filing of lawsuits in different jurisdictions.

${ }^{25}$ The discursive limitations of the European legal order owing to its allegiance to the market as the primary signifier may hinder the articulation of different interests and 'justice stories' (Roy 2014).

${ }^{26}$ Concerns regarding moral and social legitimacy have the potential to come to the fore during judicial review of the constitutionality of legislative and executive acts (Fallon $\mathrm{Jr}$ 2005). Citizenship cases expand the hermeneutic space for questioning the legitimacy of legislative and executive acts, but the tools and manner of such contestation is restricted by the available tools and mechanisms of invoking judicial review in the European legal order (Gormley 2005).
} 
to self-regulation by adherence to the IOSCO Code of Conduct. Before we proceed to a discussion of the relationship between ratings and regulation in the European legal order, the role of the IOSCO and the relationship between ratings and the transnational regulatory regime merits some attention.

Along with G-20, the Basel Committee on Banking Supervision (BCBS) and the newly empowered FSB, the IOSCO constitutes the public-private transnational financial governance complex. None of the instruments they produce including standards, codes, guidelines, declarations have binding legal authority; there is no process of ratification to make such recommendations binding upon nations. This does not, however, necessarily dilute their influence on regulation; rather, the impact of 'soft' international law of ratings on the formulation of law in national and supra-national regimes has been profound.

The method of influence of ratings on regulation has neither been through coerced implementation by countries, nor through protracted institutional lobbying as conducted by the International Accounting Standards Board (IASB), ${ }^{27}$ for instance, but through the diffusion of private regulatory networks assuming 'discreet' 28 public authority. ${ }^{29}$

As the work of comparative legal scholars suggests, diffusion appears to be the way in which sites of "social authority in an age of globalization" (Westbrook 2008) are perpetuated; thus, rather than conceptualizing transnational law in spatial or universal terms, the sites and networks that determine the boundaries and rules of a field of law would be better signifiers (Dezalay \& Garth 2011).

Whereas for Basel and IOSCO, the reliability, transparency and, most recently, the market concentration of ratings are main issues of concern, the input of CRAs to banking and securities regulation has been unquestioned.

\footnotetext{
${ }^{27}$ The accounting standards produced by the IASB are influenced by several lobbyists with diverse interests (Hansen 2011). Referring to the IASB's predecessor, the International Accounting Standards Committee, Kirsch \& Day (2001) observe "[t]he IASC itself lobbied external parties in efforts to gain support for its activities and proposed standards."

${ }^{28}$ See discussion above on Huault \& Richard's (2012) identification of international financial governance as 'discreet regulation.' Their framework regards the maintenance of order as the function of regulation. Given their influence on national and supra-national law, the products of such governance (as standards and codes) could be construed to wield regulatory authority.

${ }^{29}$ The potency of Basel, for instance, is captured by Zaring (2009): "There is no question that the Basel II will be re-evaluated sooner rather than later, but perhaps one lesson of the crisis is not that a regulatory network failed, but rather that a regulatory network made a difference [emphasis added]; it was the Basel Committee that set the standards that Bear Stearns, Lehman Brothers, and the big European banks met in practice, and it was Basel II that did not, in the end, sufficiently keep the banks solvent."
} 
The regulatory licensing of the CRAs through U.S. law, coupled with and reinforcing the CRAs' influence arising from market concentration, entered into the transnational sphere and developed an own dynamic, rendering such phenomena amenable to diffusion.

\subsubsection{Cementing the relationship between ratings and regulation in the European legal order}

The primary method by which the non-binding authority of international instruments has found a place in the EU normative framework has been the body of default standards for self-regulation of CRAs. Recently, this method has attained regulatory endorsement through the "comply unless justified otherwise' mechanism, where deviance from the model's codes and standards has to be explained. In the past, this requirement revealed that the main CRAs were in compliance with most of the provisions of the IOSCO Code, with the exception of conflicts of interest provisions regarding performing ancillary services for rated entities (Amtenbrink \& De Haan 2009, p. 22).

The current relationship between ratings and EU regulation could be characterized as a legislatively enabled ${ }^{30}$ 'IOSCO +' approach where through explicit federal regulation many gaps in the IOSCO Code have been filled such as defining the nature of ancillary services (Annex 1, section B. 4, Commission Regulation 2009), rotation of personnel to avoid conflicts of interest, the prevention of compensation of employees in CRAs contingent on the revenues received from rated entities, and the differentiation of ratings for structured products. The concentration is on preventing misconduct through extensive registration processes and oversight of the working of CRAs primarily through disclosure mechanisms. Further, the reach of EU supervision is enhanced not only internally by shaping Member State mechanisms of arresting conflicts of interest and professional misconduct, but by subjecting rating agencies of other countries to EU registration requirements and the establishment of equivalence, a move that has even been dubbed as 'regulatory imperialism' (Charles 2010).

It has been argued that the reactionary attitude of EU regulators to the crisis would lead to the maintenance of reliance by private entities or public bodies on CRAs, and may, instead of encouraging non-third party (private) due diligence, even enhance it due to the dual mechanism of endorsement through oversight, and acquiescence to the authority of ratings other than

\footnotetext{
${ }^{30} \mathrm{EU}$ institutions have endorsed the revised IOSCO Code as the "global benchmark" for "substantive requirements." European Commission, Proposal of the European Parliament and of the Council on Credit Rating Agencies, COM(2008)704 final, Brussels (12 Nov. 2008), p. 3.
} 
individual instances of misconduct (Amtenbrink \& De Haan 2009, Goodhart 2008). Amtenbrink \& De Haan (2009) go so far as to suggest that the current regulatory framework "would probably not have prevented" the role of CRAs in contributing to the crisis (ibid, p. 1945), as the regulations do not speak to causes such as the creation of "the largest possible pool of standardised, highly rated securities from the underlying pool of mortgages" (ibid, p. 1944). They forward the view that dismantling the market concentration of the CRAs, and the method of compensation, can assist with addressing these issues. We partially agree with this reasoning, as not keeping a check on market concentration would allow the path-dependent reliance on ratings to continue. However, the argument that private (non-third party) due diligence may lead to the consideration of alternatives to CRAs is unfounded in a scenario where market practice yields to the convenience of depending on such agencies, thereby maintaining the status quo.

Similar to the U.S., the regulatory reaction to the crisis in the EU has been characterized by an attribution of responsibility to the CRAs, usually by checking for cases of misconduct. This endorses a dispositionist view of law, where agents are seen as functioning individual entities with no embeddedness in structures which they help to perpetuate, and by which they are sustained. Though the 'new dynamic' of the crisis has reinforced the view that the 'public good' role of CRAs requires their examination in the spheres of risk reduction and consumer protection in addition to finance, they are analyzed by a rather closed epistemic community of finance experts which operate within the discourse of financial regulation.

This limited discourse and the related influence of an elite epistemic community is legitimized through the formal procedure of consulting 'other stakeholders.' In the most recent public consultation of 2010 regarding amendments to the 2009 Regulation in the EU, the stance taken by CRAs regarding 'Overreliance on Credit Ratings' appears to have gone effectively unchallenged. The manner and discursive choices in which consultations are conducted reveal that a 'law as policy' approach pre-determines both the relevant participants ${ }^{31}$ and thus the concerns of stakeholders. ${ }^{32}$

\footnotetext{
${ }^{31}$ In relation to the European legal order, the participation of relevant parties and stakeholders in the policy-making process is predetermined; "the formal openness of the policy process belies a reality in which a relatively small, Brussels-centred policy community dominates discussions and policy choices. More troubling, the extensive formal and informal mechanisms for societal actors' direct access to policymaking skew these discussions heavily in favour of interests" (Mügge 2011, p. 69). Further, the economic concerns of the periphery of the European Union have been argued to defer to the financial concerns of the center (Kukovec 2012).

${ }^{32}$ Taupin (2013, p. 554) argues that actors such as "investors, pension fund representatives, support the legitimacy that significantly went against their interests in the recent
} 
All three CRAs condemned the over-reliance or inappropriate use of thirdparty or external ratings, including the "exclusive use" by regulatory regimes in the assessment of creditworthiness. At the same time, CRAs appealed to their comparative strength by qualifying their shortcomings and observing that "the Commission should not present them as an inferior measure of credit risk when compared with the alternative credit risk measures being considered." 33 Specifically, market-based instruments such as credit default swaps (CDS) and credit spreads were warned against owing to their vulnerability to the vagaries of the market, as well as the general inadequacy of market prices as a proxy for credit risk analysis. In contrast, "fundamental credit analysis" would be less volatile given facets such as experience and transparency. Based on this analysis, Standard \& Poor's argued that as ratings remain a "valuable common language" for market participants (in a similar vein, Moody's advocates the maintenance of the "international common language of credit" ${ }^{34}$ ) it would be inadvisable for regulators to require market participants to abandon ratings in favor of other benchmarks and instruments. In order to support their position of comparative advantage by virtue of the construction and maintenance of the common language of credit, they denied that the ratings industry had a market concentration problem, suggesting instead that "there is vigorous competition among CRAs in relation to price, quality and service." ${ }^{35}$ Moody's provided a point-by-point response to the Commission's questionnaire and the preferred response for most questions was: "We defer to market participants with respect to what would be of assistance to them." This response captures the general inclination of the CRAs towards the maintenance of the status quo.

While the market concentration and epistemic authority of CRAs has historically been licensed by U.S. regulation, transnational financial policy governance has led to the diffusion of this authority. The third step consisted in the cementing of this authority in the European legal order. In relation to international financial standards and regulation of derivatives, Newman \& Bach (2014) have shown that the EU acts as a "hardening agent" of international soft law; "the EU - advertently and at times inadvertently-transforms and institutionalizes informal voluntary best practices into domestically embedded legal rules, thereby shaping global diffusion dynamics." In relation to

financial crises." He suggests that incommensurable, opposing views can produce a maintenance process. We, however, argue that the explanation lies in epistemic deep capture.

${ }^{33}$ Standard \& Poor's, Response to European Commission Public Consultation on Credit Rating Agencies, November 5, 2010, p. 2.

${ }^{34}$ Moody's Investor Services, Response to European Commission Public Consultation on Credit Rating Agencies, January 7, 2011, paragraphs 1.6, 1.8 and 2.2.

${ }^{35}$ Moody's, supra, p. 13. See also Standard \& Poor's, supra, p. 8. 
credit risk assessment, the EU not only hardens the relationship between ratings and regulation, but mandates the diffusion of this hardened relationship by legally requiring other countries doing business with the EU to subscribe to, or adopt equivalent rules of credit rating. Through the dual mechanism of internal certification and external requirement of equivalence ${ }^{36}$ in foreign regulations, the EU's legal framework on CRAs appears poised for shaping the international influence of CRAs per its own requirements. ${ }^{37}$ The current importance accorded to rating agencies in the European legal order appears to be poised for shaping the legal relationship between ratings and regulation globally.

\section{3 'Credibility excess' as a moderator of the regula- tory use of ratings}

If we were to characterize experts as 'speakers' and regulators as 'hearers,' a credibility excess could be attributed to experts over time and/or space, whereby the hearer makes an unduly inflated judgment of "the speaker's credibility, perhaps missing out on knowledge as a result" (Fricker 2007, pp. 16-17). We borrow this conceptualization from Miranda Fricker who concentrates mostly on 'credibility deficit' as a form of epistemic injustice where the speaker is underestimated by the hearer. She, however, also accommodates the possibility of a credibility excess that distorts any epistemic exchange, and may, on occasion, also constitute epistemic injustice for the speaker if this credibility excess leads to an inflated precarious 'epistemic arrogance' (ibid, p. 20); a bubble that can burst. One may ask - how does credibility excess come about, and why does the hearer make an unduly inflated judgment, and give in to a form of epistemic acquiescence? Given the new dynamic of the crisis, should regulators not alter their method of hearing?

Per Fricker, 'pure' power structures condition the credibility attributed to the speaker, and make it difficult for the hearer to actively change the way the speaker is heard. ${ }^{38}$ To understand the power structures that affect

\footnotetext{
${ }^{36}$ For the methodology employed by the ESMA in determining equivalence, see ESMA, Final Report on Technical advice on CRA regulatory equivalence - US, Canada and Australia, available at: http://www.esma.europa.eu/content/Technical-advice-CRAregulatory-equivalence-US-Canada-and-Australia. For an overview of the constitutional and administrative law issues regarding ESMA's powers of determining equivalence, see Alcubilla \& Del Pozo (2012), Schammo (2011).

${ }^{37}$ This is similar to the processes employed by the EU in the case of the financial transaction tax, in which international law is shaped through the EU's economic relations with other countries. For an overview, see Kochenov \& Amtenbrink (2013).

${ }^{38}$ Even in particular cases in which proactive agent power cannot be identified, the 'pure structure' perpetuates itself passively through the "reason's entanglement with social
} 
ratings and regulation, we turn to Mügge (2011) who shows that the profile and expertise of the stakeholders who contribute to the regulation of finance in the EU are embedded in the functioning of international capital and debt markets. The privileging of special interests and the corresponding exclusion of different stakeholders is the power structure that shapes the discourse on finance regulation. Thus, the functional end of regulation or legitimate output (whether it is the stability of the economy or a reliable assessment of risk) is distorted by the interests that shape the selective input (thus compromising the democratic nature of input legitimacy), whereby the maintenance of power structures enables and safeguards the politicized output.

Mügge's identification of agents with special interests that create and perpetuate these power structures may be extended to the epistemic space via Fricker's insight on the maintenance of 'pure' power structures through a privileged discourse. Combining these two accounts, which might help explain the agency paradox, is that political interests have created a "pure power structure' of 'epistemic deep capture ${ }^{39}$ — what confers legitimacy onto the relationship between ratings and regulation is the perpetuation of pathdependent aspects of financialization through the "universal common language' of risk assessment.

The insistence on the merits of a common language of risk assessment by the CRAs is a legitimizing strategy: it is an instantiation of a constitutive discourse that accords continuity to the social order that structured the credibility and pervasiveness of a certain language of risk. Given that the CRAs were instrumental in creating this common language, ${ }^{40}$ assessing its universality and functional utility is limited to the epistemic parameters demarcated by the CRAs. Further, given that regulatory concerns regarding conflicts of interest and liability for commercial speech are recent developments, the influence behind and nature of such demarcations have not been historically subject to the test of legal legitimacy. Thus, when legislators and regulators consider the legitimacy of ratings through testimony and expert opinions (even by adopting transparent procedures), these considerations occur in the shadow of the constitutive discourse of CRAs.

power" (Fricker 2007, pp. 8-11).

${ }^{39}$ This conceptualization is based on Jon Hanson and David Yosifon's (2003) framework of 'deep capture,' where the universalization of particular interests is perpetuated even without the moderating force of deliberate strategic interests. Thus, the prevalence of such capture in regulatory functioning and law-making is more difficult to identify than Stigler's (1971) classic identification of regulatory capture, which was premised on identifiable regulatory incentives in favoring certain private interests (Hanson \& Yosifon 2003).

${ }^{40}$ David Beers, Standard \& Poor's Global Head of Sovereign Ratings, spoke of a 'common language of credit risk that we at S\&P helped to invent' (Bruner \& Abdelal 2005, p. 193). 
However, the satisfaction of legitimacy would appear to be very different if the relevant social order was conceptualized as one that includes facets of the economy, politics, and indeed of everyday life that are affected by the sphere of transnational finance. For this purpose, the social legitimacy of ratings needs to be moderated by the 'law as values' rather than the 'law as policy' approach in order to interrogate the rational basis of the role CRAs assume in the financial system. Instead, the authority and functional role of ratings may be assessed against the values that allow their justification in relation to different societal interests, given the CRAs' impact on the fate of whole economies. There may be little evidence to suggest that preserving the authority of CRAs would be functional for political and societal stability.

From the responses provided by the CRAs in the public consultation, and the reliance placed on the forms of governance that were involved in the crisis, it appears that there is a move towards the legitimation of the status quo. Such legitimation is perpetuated by new measures that do not seek to destabilize "the acceptance of widespread consensual schemas/beliefs and patterns of behaviour" (Johnson et al. 2006, p. 54). Instead, what the current regulatory moves within the EU and the U.S. seek to do is to arrest deviation, or individual instances of arbitrage. The model of 'comply unless justified otherwise' regarding the adoption of the IOSCO Code of Conduct in the EU, and the model of penalization for professional misconduct being adopted in the U.S., do not try to arrest structural aspects of the governance of credit through its private evaluation.

If the relationship between ratings and regulation is oriented towards the maintenance of credit-based "casino capitalism," 41 then the social order, and regulatory endorsement of an elite field of finance witnessed so far could be construed to be legitimate. However, if the legal order that is sought to be built is one where the justification of authority is the underlying rule, and where such justification can be meaningfully contested, then a change in the discursive outlook of regulators is much needed.

To us, it seems strange that regulatory reforms drafted in the EU and U.S. do not consider the instrumental character of the reforms in the achievement of social ends; and as ratings have a compelling effect on different facets of the economy, such facets should be the focus when considering whether to remove references to ratings, or interrogating the methodology of ratings. The explanation appears to be that there are no justified alternatives to ratings for taking into account the various ends that such exercises serve, and that

\footnotetext{
${ }^{41}$ We borrow this term from Strange (1997). For a recent application of Strange's work to the constitutionalizing of a certain type of speculative risk-taking as an integral part of the "common sense" of international financial governance, and a construct that is legitimized by "scant societal consensus," see Cutler (2014).
} 
would warrant their retention in regulation. Some facets of risk assessment may require deference to rating agencies and to the methodologies they employ. However, these considerations are speculative in the absence of credible alternatives that would allow for a meaningful assessment of comparative benefits. Much like the subsidization of renewable energy technologies, we see the need for the legal facilitation of the development of alternatives to credit ratings, and regulatory investment in the promotion of competition, rather than deferring to the demands of the marketplace, as the CRAs have requested.

\section{Exit strategies}

\section{TINA?}

When it comes to considering exit strategies out of the agency paradox, one rationale for legitimizing the status quo is the so-called 'TINA' (There Is No Alternative) argument. But to what extent is this apparent knockout argument valid? If the lack of alternatives to assess creditworthiness is an outcome of the existing regulatory framework, then 'TINA' can be regarded as a path-dependent construct. The current market structure and the unsatisfactory state of knowledge concerning creditworthiness assessment should incentivize a turning point from the status quo.

Further, it may be asked - are the first attempts in the U.S. to end the regulatory hard-wiring on ratings not indicative for the spurious nature of the TINA argument? ${ }^{42}$ To what extent has the argument of the 'lack of alternatives' become the rationale itself for maintaining the use of external ratings, i.e. TINA for what? Insisting on TINA may entrench the obliviousness of rationales for the incorporation of ratings in regulation.

Due to the unrepeatability of history, the counter-factual of what would have happened in the rating industry if market forces had worked cannot be tested against empirical evidence. If the corroboration of market power via regulatory incorporation has facilitated the pervasiveness of CRA ratings, then the existing market practice can be regarded as a co-product of this regulatory framework. This implies that an exit strategy à la 'let the market decide' as suggested by the CRAs, is probably prone to perpetuate the status quo. ${ }^{43}$ This is why an active promotion of alternatives may be

\footnotetext{
${ }^{42}$ We want to thank Manfred Gärtner for pointing this out in an insightful discussion.

${ }^{43}$ Post-crisis empirical evidence of the market practice suggests that CRA reliance persists "particularly in private contracts, investment mandates, internal limits, and collateral agreements" (Financial Stability Board 2014, p. 2). For a further discussion of the role of
} 
required to change the market practice, otherwise the CRAs' authority and consequentiality may perpetuate itself.

If we may use an analogy: Suppose you promote mono-cropping and then, ceteris paribus, you claim the impossibility of a more varied vegetation, your argument can only be valid if the mono-cropping produces irreversible externalities which prevent a breeding ground for biodiversity to emerge again. Given that in social systems such as financial markets the claim of 'points of no return' are often socially constructed, it is hardly conceivable that the rules of the game are unchangeable to the extent that the externalities produced by the paradox are entirely irreversible. The transition phase, undoubtedly, will take a long time, given the force of habit. The persistence of, and the difficulty to change, the status quo has already become tangibly visible in the newest attempts to create less rating dependent regulation under the initiative of the Financial Stability Board (FSB), as discussed below. The change in market practice is supposed to be very costly; prerequisites would have to change so that alternatives can emerge in order to make a turning point feasible. However, it may be yet more costly if we cling to the TINA narrative, thereby substantiating the desirability of changing the status quo.

The exit strategies discussed in the pre-crisis literature concentrated primarily on the dichotomy between "more institutional control" and "ratingindependent regulation" (Bruner \& Abdelal 2005, p. 211). The former implies a stronger regulation of the agencies, which seems to be in line with the current course of events. Whereas, the latter usually implies a replacement of ratings "with a more market-based measure." As far as the replacement of ratings is concerned, not only is the spectrum of alternatives limited due to path dependency (as the alternatives remain 'unknown unknowns'), but concerns and critiques regarding the known alternatives warrant attention. For example, market-based measures such as credit spreads may be hardly capable of eliminating the problems created by the use of credit ratings, be it procyclicality, herd behavior or cliff effects. The reliance on market-endogenous measures for credit risk regulation may increase market volatility and even exacerbate legitimacy concerns.

Since the existing market-based alternatives do not represent an exhaustive basis to assess the superiority of CRA ratings as regulatory tools, the application of what Buchanan \& Keohane (2006) coined the "comparative benefit standard" is actually impossible. According to this standard, output legitimacy of a regulatory arrangement can be claimed as long as the same arrangement leads to substantive and procedural outcomes which are superior to those expected in the absence of it. If, however, the 'epistemic-

CRA ratings in market-based financing, see Mennillo (2014). 
deliberative' quality of a regulatory arrangement preempts the possibility of comparing alternatives, then the comparative benefit standard cannot be satisfied a priori, and the output legitimacy is in question (ibid, pp. 422-426). Thus the construction of an artificial barrier to epistemic access conditions the impossibility of a verification of a comparative benefit. In turn, the epistemic arrogance, informed by the utility of the "common language of credit risk," moderates this impossibility: a constitutive discourse becomes the only discourse - predetermining the limited range and quality of exit strategies, underpinning the dead end of a seemingly irreversible marriage.

\section{The initiative of the FSB}

Given the post-crisis consensus that regulatory reliance on CRAs materializes in mechanistic obedience to the CRAs' opinions, the FSB, which was commissioned by the G-20 in the aftermath of the crisis "to promote financial stability," represents an important advocate as regards the dis-empowerment of the CRAs. In October 2010, the FSB released the "Principles for Reducing Reliance on CRA Ratings" (Financial Stability Board 2010).

At the time of writing this article, a thorough assessment of the efforts to end the mechanistic reliance was difficult. However, the FSB's self-evaluation in its peer review report (dated May 2014) may be remedying in this regard, revealing the likely perpetuation of the agency paradox. The "Thematic Review on FSB Principles for Reducing Reliance on CRA Ratings" (Financial Stability Board 2014) aims "to assist national authorities in fulfilling their commitments under the Roadmap [(Financial Stability Board 2012)]." The main demand posed to national authorities is an "acceleration of the progress [...] to implement fully the agreed Roadmap" (Financial Stability Board 2014, p. 1). The "strengthening of internal credit assessment capabilities" and the "development of alternative standards of creditworthiness" represent hereby the biggest challenges for the realization of its principles. Furthermore, the "time required to build-up or enhance own credit risk assessment capabilities (especially for smaller entities) are hindering progress" (ibid).

In accordance with the Roadmap, the FSB conceives of CRA ratings to be "no more than an input to credit risk assessment" by the end of 2015 . Against the background of the slowness in implementation, this goal seems increasingly unrealistic. In view of the variety of the action plans "in terms of scope and ambition level," the general approach of "national action plans" [emphasis added] may also reveal not to be the most promising path for sticking to the original resolutions of 2010. Compounding the problem is also the variation of member state's approaches "across jurisdictions and financial sectors." There seems to be disagreement concerning both "the volume of 
measures to be taken and the policy areas that they cover." It is unlikely that the FSB will be able to overcome these differences among its members. In line with the FSB's moderator role, the main recommendation it gives as regards the 'how to' find alternatives of creditworthiness assessments consists of an enhanced dialog of national authorities with market participants.

There is enough reason to presume that the FSB has recognized its quasi 'mission impossible;' the FSB starts to demand the 'feasible.' In the meantime, it has adopted a double substitution strategy: to substitute the increasing reliance on internal ratings for the reliance on external ratings, and to advocate an enhanced oversight of CRAs in accordance with the IOSCO code of conduct. ${ }^{44}$ This combination of targeted measures can be regarded as a compromise with respect to the initial resolutions - as a substitution strategy 'light.'

It requires further research to assess whether the FSB did not go far enough with its agenda from the very beginning - even though it may be questionable whether the FSB would have had the necessary weight to credibly ask for more. With the Progress report to the St. Petersburg G-20 Summit (Financial Stability Board 2013) its claim to reduce the CRA reliance has been amended by the claim for "increased oversight." If a watering down of the FSB's initiative is looming ahead, given the deceleration and postponement of the efforts by national authorities, it does not come as a surprise that the FSB may start to adopt a rhetoric in which the increased regulation of CRAs serves as a further substitute for plans to reduce the regulatory reliance on ratings.

In the end, the success of the FSB's efforts depends to a great extent on the determination of the BCBS, as the Basel regime remains the most compelling international influence behind the regulatory reliance on external ratings. That is why the FSB seems to literally wait for the BCBS's action. ${ }^{45}$

\footnotetext{
${ }^{44}$ The FSB explicitly claims the improvement of the "transparency and competition among CRAs" (Financial Stability Board 2013, p. 5) and asks for more disclosure "about rating methodologies, rating performance, conflicts of interest, and other operational matters." It relies on other standard setters as IOSCO to "provide guidance to their members on steps to further discourage reliance on CRA ratings."

${ }^{45}$ The BCBS still seems to hesitate to put in place concrete measures. The reform is still pending, and it will require further research to analyze the dynamics of the BCBS's postponement, and the role member states and private interests played therein. The St. Petersburg progress report announced (Financial Stability Board 2013, p. 1 ): "The Basel Committee for Banking Supervision (BCBS) has made proposals to reduce reliance in its securitisation framework and by mid-2014 will make proposals on reducing reliance within its standardised approach for capital requirements." Nine months later, the Financial Stability Board (2014, p. 7 ) declared: "For credit risk, the BCBS is in the process of reviewing the standardised approach and the securitisation framework with a view to reducing un-
} 


\section{Back to Basel I?}

What would happen if legal codification of CRA ratings belonged to history? Would the global financial markets pose less systemic threats to the wealth and stability of whole nations? Even if we abolish external ratings as 'language' of credit risk, the substitution strategy endorsed at the moment by transnational bodies aims at finding other 'languages of risk.' In principle, the continuity with respect to the central role risk-based bank capital standards play in financial regulation has been maintained. The incremental character of the recent reform efforts suggests the desirability and superiority of risk-sensitive measures for the regulation of credit risk as opposed to non-risk-sensitive measures. Porter (2014, p. 12) diagnoses the "continuity in the content of the rules" as symptomatic of the "incremental character of the transnational response to the crisis" - a seemingly general pattern, which can also be found in other areas of financial reform. ${ }^{46}$

Given the experienced failures to capture risk adequately with the current regulatory approach, it is tempting to ask: Why not abandon the idea of delegated risk-differentiation in regulation and return to Basel I? It does certainly go beyond the scope of this paper to discuss this question thoroughly. But the fact that the crisis was not lesson enough, to at least question critically the rationales of delegated, risk-sensitive regulation seems striking. The taken-for-granted continued use of different languages of risk (be it internal or external ratings) as an indirect regulatory tool, can be read as the ever "growing trend toward private ordering of traditionally public functions" Schwarcz (2002) - underpinned by the crisis. What concerns financial regulation in general, and the determination of CAR of banks in particular, the transition from Basel I to Basel II can be categorized as a key moment of this trend. The replacement of institutional variables based on 'volume,' has been done by the category of 'risk' (Besedovsky 2012, Poon 2012). Importing 'risk' as the main language to define CAR, implied the delegation of regulatory tasks to models and entities capable of 'talking' about risk. This seemingly irreversible dependence can be regarded as the price for having

due reliance on CRA ratings in the regulatory capital framework (in Pillar 1). Most FSB members plan to make further progress towards reducing reliance on CRA ratings in bank capital adequacy requirements within eighteen months after the Basel Committee finalises its work on the securitisation framework and the standardised approach for credit risk, which are expected around end-2014 and mid-2015, respectively."

${ }^{46}$ For a concise overview of the financial reforms after the crisis, and a discussion about the continued delegation of "discretion to private actors" therein, see edited volume by Porter (2014). 
allowed a higher risk differentiation in regulatory matters. Thus the mentioned trend of delegated regulation cannot be exclusively read as a simple unwillingness 'to do the job' on the part of public authorities, but also as a zeitgeist phenomenon of finance where static understandings of regulatory capital requirements became out-of-date - revolutionizing old-fashioned ways of financial regulation straight away.

\section{Internal ratings}

The replacement of external ratings by internal risk models also has its downsides, especially for smaller banks. Internal ratings represent a competitive cost advantage for larger banks. For the latter, producing internal ratings is relatively affordable, whereas smaller competitors can save relatively large resources if they can outsource creditworthiness assessment to a third-party, i.e., to a CRA. ${ }^{47}$ This rationale is often mentioned as a central, practical reason to have embedded CRA ratings in regulation. Lall (2012), for example, criticizes the "advanced internal ratings-based approach" (A-IRB) adopted in Basel II precisely for this reason. He argues in favor of the incorporation of external ratings in the standardized approach as this would improve the level playing field. Another critique of the A-IRB approach points to its inherent incentive for banks to underestimate risk. Since capital adequacy requirements are seen as "regulatory taxation" (in normal times), system-wide capital buffers are expected to be even lower with internal ratings-based regulation, so the argument goes.

\section{Conclusion}

The incorporation of ratings into regulation represents an illustrative case for the tacit empowerment of market actors such as CRAs by public bodies. The codification of the CRAs' authority would not have been possible without the delegation of 'governance' functions through the back door, and without the confidence in 'market practice.' Although in the aftermath of the crisis policymakers have shown attempts to limit the CRAs' influence by inducing banks to rely more heavily on their own creditworthiness assessments, these efforts are often found to be half-hearted. As long as markets, central bankers and regulators perpetuate the practice, the CRAs' authority will probably remain intact - regardless of the political implications.

\footnotetext{
${ }^{47}$ These conflicts of interest between advocates of small financial institutions and larger banks have been a central issue of controversy in the U.S. negotiations about the implementation of the Basel II accord. For a concise discussion see Tarullo (2008).
} 
We have tried to delve deeper into the reasons for this adherence, or "deep capture." We note that the explanations provided by different actors are tautological: Investors refer to the ratings' standard setting role when they explain their reliance on CRAs. At the same time, the BCBS and central bankers refer to market practice as a reason for not terminating the implicit cooperation with the CRAs (Basel Committee on Banking Supervision 2009, p. 55, item 183.):

One reason for using external ratings to assess capital requirements is that they provide a relatively standardised, harmonised, easy-to-understand, independent (third-party) measure that generally reflects the credit quality of a counterparty, issuer or investment product. Financial institutions and market players, in general, already used external credit ratings extensively in their risk management processes before external ratings were incorporated in the Basel II framework. In this regard, the Basel II framework is closely aligned with market practices. Hence, while the introduction of the credit ratings within the supervisory framework may not have changed market practice, it may have further legitimised the use of ratings in the minds of some market participants.

We regard the emergence of a market power "that can never be wrong" as a deeply problematic (unintended) consequence of the regulatory incorporation of ratings. This could trigger tremendous feedback effects on the epistemic authority of CRAs, favoring further legal codification of expert 'opinions,' which are legitimized by market forces (that actually do not even work). Claiming a monopoly of expertise in creating and providing the "common language" of risk shows that CRAs' themselves, in the meantime, have come to believe in the legitimacy of their own epistemic authority. It will require further research to delve into the causes and consequences of this 'language' creation.

Considering the enhanced regulation of CRAs, and their awakened lobbying, it does not seem that the history of the agency paradox is already at its end. The still pending success of the FSB's initiative may reveal that 'divorce' between ratings and regulation is becoming more and more difficult, given the seemingly irreversible consequences of the 'marriage.' Since the memory of the crisis is steadily fading out, political pressure is expected to decrease further.

A genuine overhaul of the experiences of the last years, which in our view should represent an integral part of crisis prevention, necessitates a closer look to the dynamics which led to, and continue to maintain, the authority of CRAs. Without doing this, all the regulatory efforts risk being superficial 
and costly cosmetics in the best case, and provide the breeding ground for the next crisis in the worst case.

\section{References}

Abdelal, R. (2007), Capital rules: The construction of global finance, Harvard University Press.

Abdelal, R. \& Blyth, M. (2013), Just Who Put You in Charge? We Did: Credit Rating Agencies and the Politics of Ratings. Manuscript.

Alcubilla, R. G. \& Del Pozo, J. R. (2012), Credit rating agencies on the watch list: Analysis of European regulation, Oxford University Press.

Amtenbrink, F. \& De Haan, J. (2009), 'Regulating credit ratings in the European Union: A critical first assessment of Regulation 1060/2009 on credit rating agencies', Common market law review 46(6), 1915-1949.

Amtenbrink, F. \& Heine, K. (2013), 'Regulating Credit Rating Agencies in the European Union: Lessons from Behavioural Science', The Dovenschmidt Quarterly 2(1), 2-15.

Barr, M. S. \& Miller, G. P. (2006), 'Global administrative law: the view from basel', European Journal of International Law 17(1), 15-46.

Basel Committee on Banking Supervision (2009), Strengthening the Resilience of the Banking Sector, Consultative document, Bank for International Settlements. December 2009, last access September 2014.

Besedovsky, N. (2012), Politischer Ritterschlag für Ratingagenturen: Regulatorisches Outsourcing und der Beitrag von Gesetzgebern zur Macht der Ratingagenturen, in K. Kraemer \& S. Nessel, eds, 'Entfesselte Finanzmärkte: Soziologische Analysen des Modernen Kapitalismus', Campus Verlag, Frankfurt am Main, pp. 225-242.

Bourdieu, P. (1977), Outline of a Theory of Practice, Cambridge University Press.

Brummer, C. \& Loko, R. (2014), The New Politics of Transatlantic Credit Rating Agency Regulation, in T. Porter, ed., 'Transnational Financial Regulation after the Global Financial Crisis', Routledge/RIPE Series in Global Political Economy, Taylor \& Francis Group, pp. 154-176. 
Bruner, C. \& Abdelal, R. (2005), 'To Judge Leviathan: Sovereign Credit Ratings, National Law, and the World Economy', Journal of Public Policy 25(2), 191-217.

Buchanan, A. \& Keohane, R. (2006), 'The legitimacy of global governance institutions', Ethics $\&$ International Affairs 20(4), 405-437.

URL: http://dx.doi.org/10.1111/j.1747-7093.2006.00043.x

Carruthers, B. G. (2013), 'From uncertainty toward risk: the case of credit ratings', Socio-Economic Review 11(3), 525-551.

URL: http://ser.oxfordjournals.org/content/11/3/525.abstract

Carruthers, B. G. \& Halliday, T. C. (2007), Law, economy and globalization: Max Weber and how international financial institutions understand law, in V. Nee \& R. Swedberg, eds, 'On Capitalism', Stanford University Press, pp. $128-151$.

Charles, K. S. (2010), 'Regulatory Imperialism: The Worldwide Export of European Regulatory Principles on Credit Rating Agencies', Minnesota Journal of International Law 19, 399-451.

Claessens, S. \& Kodres, L. (2014), The Regulatory Responses to the Global Financial Crisis: Some Uncomfortable Questions, IMF Working Papers 46, International Monetary Fund (IMF).

Cohen-Eliya, M. \& Porat, I. (2011), 'Proportionality and the culture of justification', American journal of comparative law 59(2), 463-490.

Cutler, A. C. (2014), 'Strange bedfellows? bankers, business(men), and bureaucrats in global financial governance', Princeton University Workshop, "A Retrospective on the Work of Susan Strange: Structure, Power, Knowledge, and Norms" pp. 1-33.

Darbellay, A. \& Partnoy, F. (2012), 'Credit rating agencies and regulatory reform', Research Handbook on the Economics of Corporate Law pp. 12-82.

Dezalay, Y. \& Garth, B. G. (2011), 'Corporate law firms, ngos and issues of legitimacy for a global legal order', Fordham Law Review 80, 2309-2345.

Dullien, S. (2013), 'Financial market reform: Still too much faith in market rationality', Wirtschaftsdienst 93(1, Supplement), 23-29.

Ellis, N. S., Fairchild, L. M. \& D'Souza, F. (2011), 'Is imposing liability on credit rating agencies a good idea: Credit rating agency reform in the 
aftermath of the global financial crisis', Stanford Journal for Law Business \& Finance 17, 175-222.

Fallon Jr, R. H. (2005), 'Legitimacy and the constitution', Harvard Law Review pp. 1787-1853.

Financial Stability Board (2010), 'Principles for Reducing Reliance on CRA Ratings'.

URL: http://www.financialstabilityboard.org/publications/[accessed 3 August 2012]

Financial Stability Board (2012), 'Roadmap and workshop for reducing reliance on CRA ratings'.

URL: http://www.financialstabilityboard.org/publications/ [accessed 11 June 2014]

Financial Stability Board (2013), 'Credit Rating Agencies: Reducing reliance and strengthening oversight'. Progress report to the St. Petersburg G20 Summit.

URL: http://www.financialstabilityboard.org/publications/ [accessed 11 June 2014]

Financial Stability Board (2014), 'Peer Review Report: Thematic Review on FSB Principles for Reducing Reliance on CRA Ratings'.

URL: http://www.financialstabilityboard.org/publications/ [accessed 14 June 2014]

Fricker, M. (2007), Epistemic injustice: Power and the ethics of knowing, Oxford University Press.

Gaillard, N. (2012), A Century of Sovereign Ratings, Springer Verlag.

Goodhart, C. A. E. (2008), 'The regulatory response to the financial crisis', Journal of Financial Stability 4(4), 351-358.

Gormley, L. W. (2005), 'Judicial review: Advice for the deaf', Fordham International Law Journal 29, 655-689.

Hansen, T. B. (2011), 'Lobbying of the IASB: An empirical investigation', Journal of International Accounting Research 10(2), 57-75.

Hanson, J. \& Yosifon, D. (2003), 'The situation: An introduction to the situational character, critical realism, power economics, and deep capture', University of Pennsylvania Law Review pp. 129-346. 
Harper, S. (2011), 'Credit Rating Agencies Deserve Credit for the 2007-2008 Financial Crisis: An Analysis of CRA Liability Following the Enactment of the Dodd-Frank Act', Washington 85 Lee Law Review 68(4), 1925-1972.

Heggen, J. W. (2010), 'Not Always the World's Shortest Editorial: Why Credit-Rating-Agency Speech Is Sometimes Professional Speech', Iowa Law Review 96, 1745-1766.

Hollis, D. B. (2005), 'Why state consent still matters: Non-state actors, treaties, and the changing sources of international law', Berkeley Journal of International Law 23, 137-174.

Huault, I. \& Richard, C. (2012), Finance: The discreet regulator: How financial activities shape and transform the world, Palgrave Macmillan.

Johnson, C., Dowd, T. J. \& Ridgeway, C. L. (2006), 'Legitimacy as a social process', Annual review of sociology pp. 53-78.

Katzenstein, P. J. \& Nelson, S. C. (2013), 'Reading the right signals and reading the signals right: IPE and the financial crisis of 2008', Review of International Political Economy 20(5), 1101-1131.

Kerwer, D. (2005), 'Holding global regulators accountable: The case of credit rating agencies', Governance 18(3), 453-475.

URL: http://dx.doi.org/10.1111/j.1468-0491.2005.00284.x

Kirsch, R. J. \& Day, R. (2001), 'Lobbying and the international accounting standards committee'.

Kochenov, D. (2008), 'Ius tractum of many faces: European citizenship and the difficult relationship between status and rights', Columbia Journal of European Law 15, 169-237.

Kochenov, D. \& Amtenbrink, F. (2013), The European Union's shaping of the international legal order, Cambridge University Press.

Krippner, G. (2011), Capitalizing on Crisis: The Political Origins of the Rise of Finance, Harvard University Press.

Kukovec, D. (2012), 'A Critique of the Rhetoric of Common Interest in the EU Legal Discourse', Available at SSRN 2178332.

Lall, R. (2012), 'From failure to failure: The politics of international banking regulation', Review of International Political Economy 19(4), 609-638.

URL: $h t t p: / / d x . d o i . o r g / 10.1080 / 09692290.2011 .603669$ 
Mennillo, G. (2014), Grease between light and shadow: Sovereign ratings and the construction of risk. Manuscript prepared for Workshop on 'Shadow Banking and Systemic Risk in Global Finance,' Boston University.

Mügge, D. (2011), 'Limits of legitimacy and the primacy of politics in financial governance', Review of International Political Economy 18(1), 52-74. URL: http://dx.doi.org/10.1080/09692290903025162

Nagy, T. (2009), 'Credit Rating Agencies and the First Amendment: Applying Constitutional Journalistic Protections to Subprime Mortgage Litigation', Minnesota Law Review 94, 140-67.

Newman, A. \& Bach, D. (2014), 'The European Union as hardening agent: soft law and the diffusion of global financial regulation', Journal of European Public Policy 21(3), 430-452.

Norrlof, C. (2014), 'Dollar hegemony: A power analysis', Review of International Political Economy, published online 17 April 2014 pp. 1-29.

URL: http://dx.doi.org/10.1080/09692290.2014.895773

Partnoy, F. (1999), 'The Siskel and Ebert of Financial Markets?: Two Thumbs Down for the Credit Rating Agencies', Washington University Law Quarterly 77(3), 619-714.

Partnoy, F. (2009), 'Overdependence on Credit Ratings was a Primary Cause of the Crisis. Proceedings of the 2008 International Banking Conference: "The First Credit Market Turmoil of the 21st Century", San Diego Legal Studies Paper (15).

Poon, M. (2012), Rating agencies, in K. Knorr Cetina \& A. Preda, eds, 'The Oxford Handbook of the Sociology of Finance', Oxford Handbooks Online, Oxford University Press, pp. 1-16.

Porter, T. (2010), Risk models and transnational governance in the global financial crisis: the cases of Basel II and credit rating agencies, in E. Helleiner, S. Pagliari \& H. Zimmermann, eds, 'Global Finance in Crisis: The Politics of International Regulatory Change', Warwick Studies in Globalisation, Taylor \& Francis, pp. 56-73.

Porter, T. (2014), Transnational Financial Regulation after the global financial crisis, Routledge/RIPE Series in Global Political Economy, Taylor \& Francis Group. 
Roy, S. (2014), Justice as Europe's Signifier: Towards a More Inclusive Hermeneutics of the European Legal Order, in D. Kochenov, G. de Burca \& A. Williams, eds, 'Europe's Justice Deficit'.

Rügemer, W. (2012), Rating-Agenturen - Einblicke in die Kapitalmacht der Gegenwart, transcript Verlag.

Schammo, P. (2011), 'The European Securities and Markets Authority: Lifting the veil on the allocation of powers', Common Market Law Review 48(6), 1879-1913.

Schwarcz, S. L. (2002), 'Private ordering of public markets: The rating agency paradox', University of Illinois Law Review 1(18), 1-29.

Sicilia, D. (2011), 'Roots of credit rating agency shortcomings', http://blogs.rhsmith.umd.edu/financialpolicy/faculty-commentary/rootsof-credit-rating-agency-shortcomings/.

Sinclair, T. J. (1999), Bond-rating agencies and coordination in the global political economy, in A. C. Cutler, V. Haufler \& T. Porter, eds, 'Private Authority and International Affairs', State University of New York Press, pp. $153-167$.

Sinclair, T. J. (2010), 'Round up the usual suspects: Blame and the subprime crisis', New Political Economy 15(1), 91-107.

URL: http://dx.doi.org/10.1080/13563460903553657

Stigler, G. J. (1971), 'The theory of economic regulation', The Bell Journal of Economics and Management Science pp. 3-21.

Strange, S. (1997), Casino Capitalism, Manchester University Press.

Tarullo, D. (2008), Banking on Basel: The Future of International Financial Regulation, Peterson Institute for International Economics.

URL: http://books.google.com/books?id=nqFEngEACAAJ

Taupin, B. (2013), 'The more things change... institutional maintenance as justification work in the credit rating industry', $M @ n @ g e m e n t$ 15(5), 529562.

van der Zwan, N. (2014), 'Making sense of financialization', Socio-Economic Review 12(1), 99-129.

Ward, I. (1996), The margins of European law, Macmillan Press. 
Westbrook, D. A. (2008), 'Theorizing the diffusion of law in an age of globalization: Conceptual difficulties, unstable imaginations, and the effort to think gracefully nonetheless', Annals-Belgrade Law Review 3, 159-179.

White, L. (2001), The Credit Rating Industry: An Industrial Organization Analysis, Working paper series: Salomon Center for the Study of Financial Institutions, New York University Salomon Center.

URL: http://books.google.com/books?id=yodQHAAACAAJ

Zaring, D. (2009), 'Three challenges for regulatory networks', The International Lawyer pp. 211-217. 